\title{
Social Media Tipping Point or Economic Remorse?
}

\section{Scott J Weiland ${ }^{*}$}

King's College of Mass Communications, United States

\begin{abstract}
Scranton Times reporter Donnie Collins reported that Laremy Tunsil, a football player from the University of Mississippi lost significant value in the 2016 National Football League draft. Collins alleged that information shared on Tunsil's social media contributed to the Tunsil's descent down the draft board and speculated that the drop cost Tunsil \$7 million dollars. A group of Mass Communications students at King's College read Collins' article, then reflected and shared their reflections. The students disagreed with Tunsil's alleged behavior, citing the need for personal responsibility for their brands on social media in accordance with their vocations. How much the loss of millions of dollars contributed to their thinking was unclear.
\end{abstract}

Keywords: Social media; Vocation; Facebook; Twitter; Mass communication; National football league (NFL)

\section{Introduction}

Collins [1] editorial in the Scranton Times regarding the meteoric drop in Laremy Tunsil's value in the 2016 National Football League (NFL) draft was a well-timed contribution to a global discussion regarding social media. In his article, Collins noted that Tunsil, a football player, specifically an offensive tackle from the University of Mississippi, descended down the NFL draft board (perhaps as the number three selection) to pick number 13. Collins speculated that the drop, which lasted about 90 minutes, cost Tunsil \$7 million dollars. What could cause such a decline?

Collins reported that about thirteen minutes prior to the draft [1], a ten-second video of Tunsil donning a gas mask and allegedly inhaling marijuana smoke was posted on Tunsil's Twitter account. Moments later, an incriminating message was shared on Tunsil's Instagram account regarding a conversation that Tunsil allegedly conducted with a Mississippi assistant football coach where he asked for money to cover some of his mother's expenses. It is not known who shared this content on Tunsil's social media. Tunsil admitted to both incidents and perhaps forever saw his brand tainted. Collins [1] noted, "Our reputations can be molded by our words on Twitter, an ill-advised photo on Facebook, or in a long-forgotten video saved to someone else's smart phone" (para. 17). Collins' commentary is accurate; could that be why Tunsil's incidents drew such ire? Perhaps, or is it more about the loss of so much money that is made Tunsil's dilemma so shocking?

\section{Impact of Social Media}

I have the great privilege of serving as Chair of the Department of Mass Communications at King's College, which is located in WilkesBarre, PA. The Department of Mass Communications offers students a balance of practical and theory-based courses. We empower students with critical thinking, research, and production skills they need to successfully compete in academic and industrial marketplaces. We challenge students to promote an ethical and equitable society in keeping with the mission of King's. We want our students to be reflective practitioners. A group of Mass Communications students at King's College read Collins' article, reflected, and shared their reflections in writing (not on social media). Twenty-five students read Collins' piece, and all indicated that they were alarmed by Tunsil's behavior...perhaps even more alarmed that such miscues were shared, particularly since Tunsil was quite a well know figure. All twenty-five shared that Tunsil's exposure on his social media was unfortunate but brought on by his own doing. Each student indicated that it is their responsibility for their behavior and their brand as it is reflected on social media. Each student also indicated that they would conduct an audit of their own social media to seek photos, videos, and commentary that are negative, damaging, or could harm their brands. I was intrigued by their comments. Could it be that the time and effort spent developing ethical and socially responsible behavior with Mass Communications students at King's College has paid off? Could it be that our rigorous assurance of learning plan, closing-the-loop discussions, and subsequent actions that are taken to apply the results of the assessment and closing the loop discussion to improve teaching and learning are bearing fruit? This may be true, but is the $\$ 7$ million dollar question the most important question to be asking?

As a group, our twenty-five discussed Tunsil's incident. As I observed their behavior during the discussion, it was clear that they knew that Tunsil's behavior leading to the sharing on his social media was wrong. They communicated this verbally and non-verbally. Their discussion was animated, and the words "stupid," "shameful," and "dumb" were often heard, with body language of those lobbing such grenades in syncopation (although a few mocking chuckles were heard). When the topic of Tunsil's social media sharing was raised, students indicated that Tunsil was perhaps a victim but should have known better than to engage in such behavior. When the topic of the potential loss of $\$ 7$ million dollars emerged, the tone of the room became tense and the volume loud; students couldn't believe that someone had let such riches slip by.

\section{Conclusion}

My work at King's College affords me the opportunity to encourage students to reflect upon their own vocations. Students are often asked: "Who are you?" "What kind of person do you want to be?" "What kind

*Corresponding author: Weiland SJ, King's College of Mass Communications 133 North River Street, Wilkes-Barre, PA 18711, United States, Tel: 570208-5202; E-mail: scottweiland@kings.edu

Received September 02, 2016; Accepted September 07, 2016; Published September 12, 2016

Citation: Weiland SJ (2016) Social Media Tipping Point or Economic Remorse? J Mass Communicat Journalism 6: 313. doi: 10.4172/2165-7912.1000313

Copyright: ( 2016 Weiland SJ. This is an open-access article distributed under the terms of the Creative Commons Attribution License, which permits unrestricted use, distribution, and reproduction in any medium, provided the original author and source are credited. 
Citation: Weiland SJ (2016) Social Media Tipping Point or Economic Remorse? J Mass Communicat Journalism 6: 313. doi: 10.4172/21657912.1000313

of person are you called to be in the world?" "What is your roadmap to get there?" "What gifts do you have?" "How are you called to use them?" "How will you share your vocation with others?" As part of this ongoing process Mass Communication students reflect and conduct an open dialog through various new and traditional media, including the spoken word. Students' "weapon of choice" for sharing is often social media, which can be a razor sharp, double-edged sword. True or false? Rather than ask Tunsil I asked my students. In the context of the discussion regarding Tunsil when asked, "What kind of person do you want to be?" students clearly and openly reflected deeply on their own behavior, social media, brand, and Tunsil's actions. It is clear that the students strongly disagreed with Tunsil's behavior. What is not clear is that if their moral compasses were spinning and/or if Tunsil's loss of a massive amount of income caused such an outcry. As noted it is not clear who shared these behavioral miscues by Tunsil but by participating in social media he left himself vulnerable, providing a window for the world to see in to his personal life. If Tunsil had never joined Instagram or Twitter wouldn't he be $\$ 7$ million richer?

Perhaps what was most important from this process is that the students spent time upon their own behavior and calling, decoding how such actions translate to their social media and negatively impact their own brands. Interestingly enough there were no comments from the public posted in the discussion forum following the article on the web site... and the forum is now closed. Perhaps the discussion about vocation and responsibility for one's own brand on social media will not end so abruptly.

\section{Reference}

1. Collins D (2016) COLLINS: Too easy to blame social media when we should be blaming ourselves- May 2016. 